$4^{\text {th }}$ International Meeting on Calcitonin Gene-Related Peptide (CGRP)

TheScientificWorld (2001) 1(S1), 38

ISSN 1532-2246; DOI 10.1100/tsw.2001.408

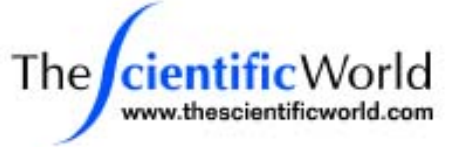

\title{
EVIDENCE FOR THE DIFFERENTIAL DISTRIBUTION OF AT LEAST TWO ADRENOMEDULLIN RECEPTOR SUBTYPES IN THE RAT BRAIN
}

\author{
J.-G. Chabot ${ }^{1}$, C. Juaneda ${ }^{1}$, Y. Dumont ${ }^{1}$, A. Fournier ${ }^{2}$, and R. Quirion ${ }^{1}$ \\ ${ }^{1}$ Douglas Hospital Research Center and Department of Psychiatry, McGill University, Verdun, \\ QC, Canada, H4H 1R3; ${ }^{2}$ INRS-Institut Armand-Frappier, Université du Québec, Pointe-Claire, \\ QC, Canada, H9R 1G6
}

We recently reported that specific $\left[{ }^{125} \mathrm{I}\right]$ human Adrenomedullin ${ }_{13-52}\left(\mathrm{hADM}_{13-52}\right)$ binding sites are very discretely distributed in the rat brain[1]. Furthermore, in rat brain membrane homogenates, we suggested the existence of at least two populations of $\left[{ }^{125} \mathrm{I}\right] \mathrm{h} \mathrm{ADM}_{13-52}$ receptor binding sites[2]. In the present study, we investigated the differential distribution of specific $\left[{ }^{125} \mathrm{I}\right] \mathrm{hDM}_{13}$ 52 sites that are sensitive and insensitive to $\mathrm{hADM}_{22-52}$ in the rat brain. Adjacent coronal rat brain sections were incubated with $35 \mathrm{pM}\left[{ }^{125} \mathrm{I}_{\mathrm{hADM}} \mathrm{hA}_{13-52}\right.$ in the presence of increasing concentrations of hADM $22-52$. As previously reported, specific [ $\left.{ }^{125} \mathrm{I}\right] \mathrm{h} \mathrm{ADM}_{13-52}$ sites were observed in the choroid and linings of ventricles, basal amygdaloid nucleus, neuronal lobe of the pituitary gland, trigeminal nucleus, and cerebellum. Specific $\left[{ }^{125} \mathrm{I}_{\mathrm{hADM}} \mathrm{AD}_{13-52}\right.$ binding is fully inhibited by $1 \mu \mathrm{M}$ $\mathrm{hADM}_{22-52}$ in all these brain regions except in the cerebellum. In fact, hADM $22-52$ was able to inhibit only $70 \%$ of specific $\left[{ }^{125} \mathrm{I}_{\mathrm{hADM}} \mathrm{AD}_{13-52}\right.$ binding sites in the rat cerebellum. These data suggest for the first time that the rat cerebellum contains at least two populations of ADM receptors, one that is sensitive to $\mathrm{hADM}_{22-52}$ while the other is resistant. This characterization of cerebellar $\left[{ }^{125} \mathrm{I}\right] \mathrm{hADM} \mathrm{AD}_{13-52} / \mathrm{hADM}_{22-52}$-insensitive sites is currently under investigation. Supported by grant from the CIHR to RQ.

\section{REFERENCES}

1. Juaneda, C. et al. Eur. J. Pharmacol., in press.

2. Juaneda, C. et al. (2000) Soc. Neurosci. 26, 382. 

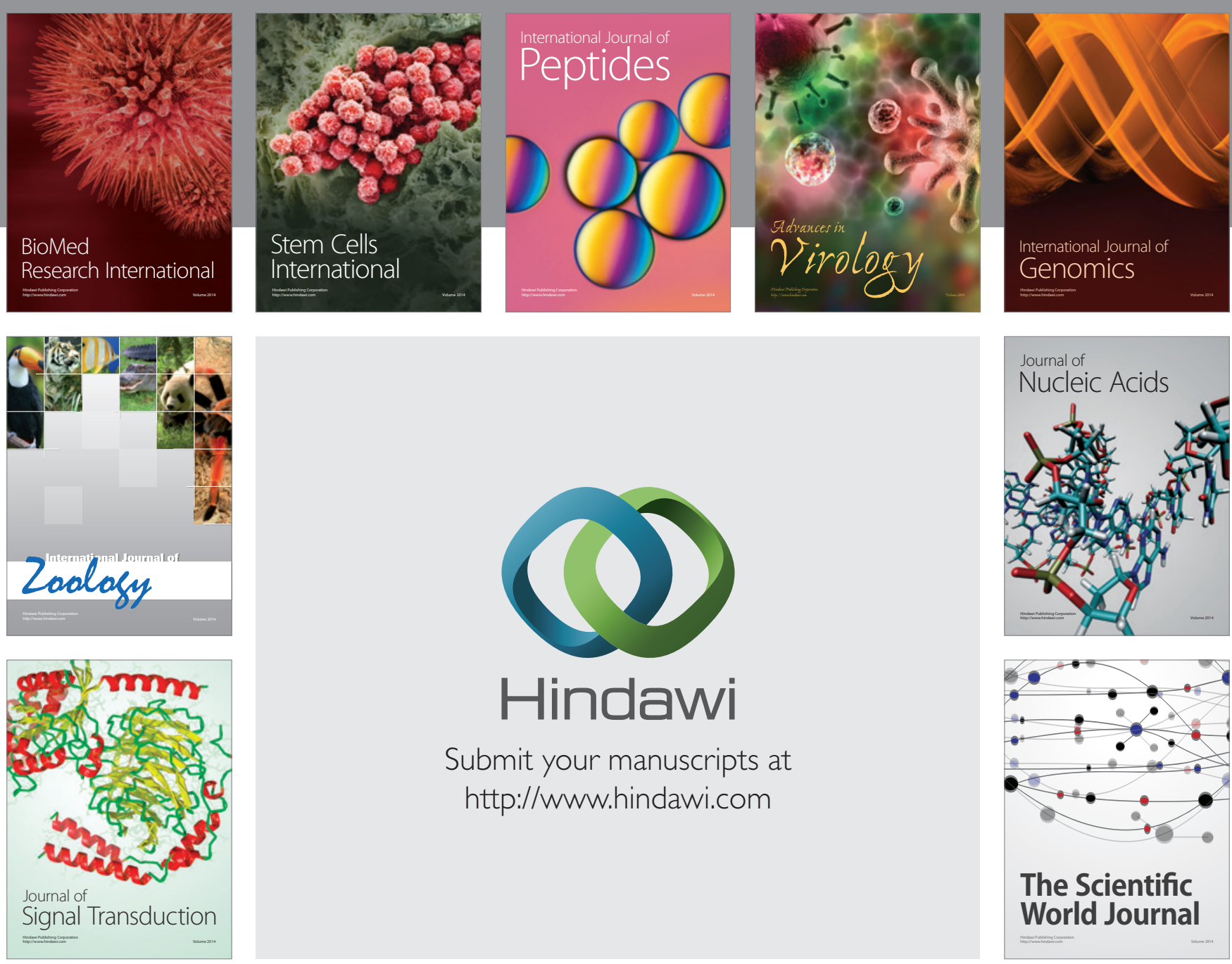

Submit your manuscripts at

http://www.hindawi.com
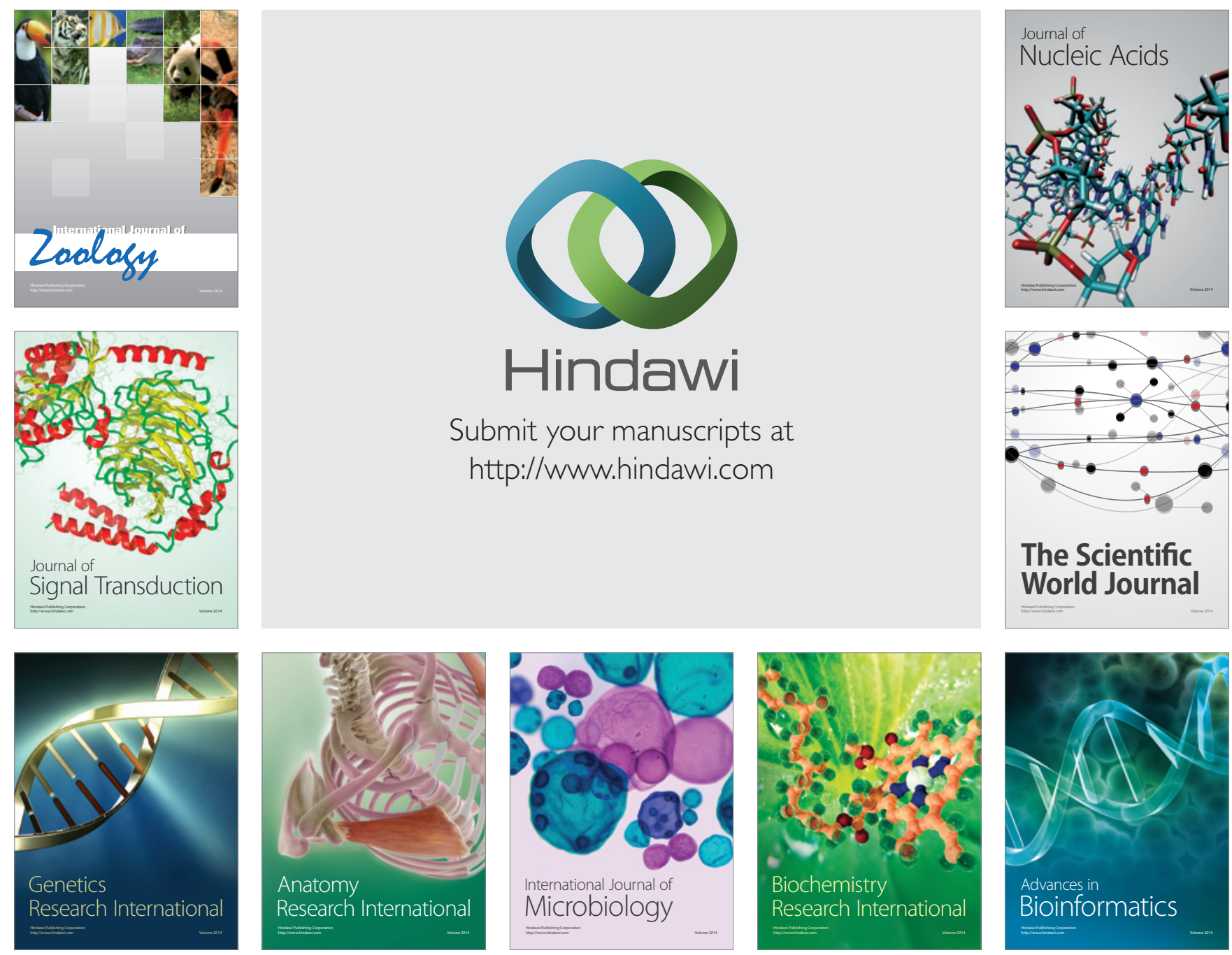

The Scientific World Journal
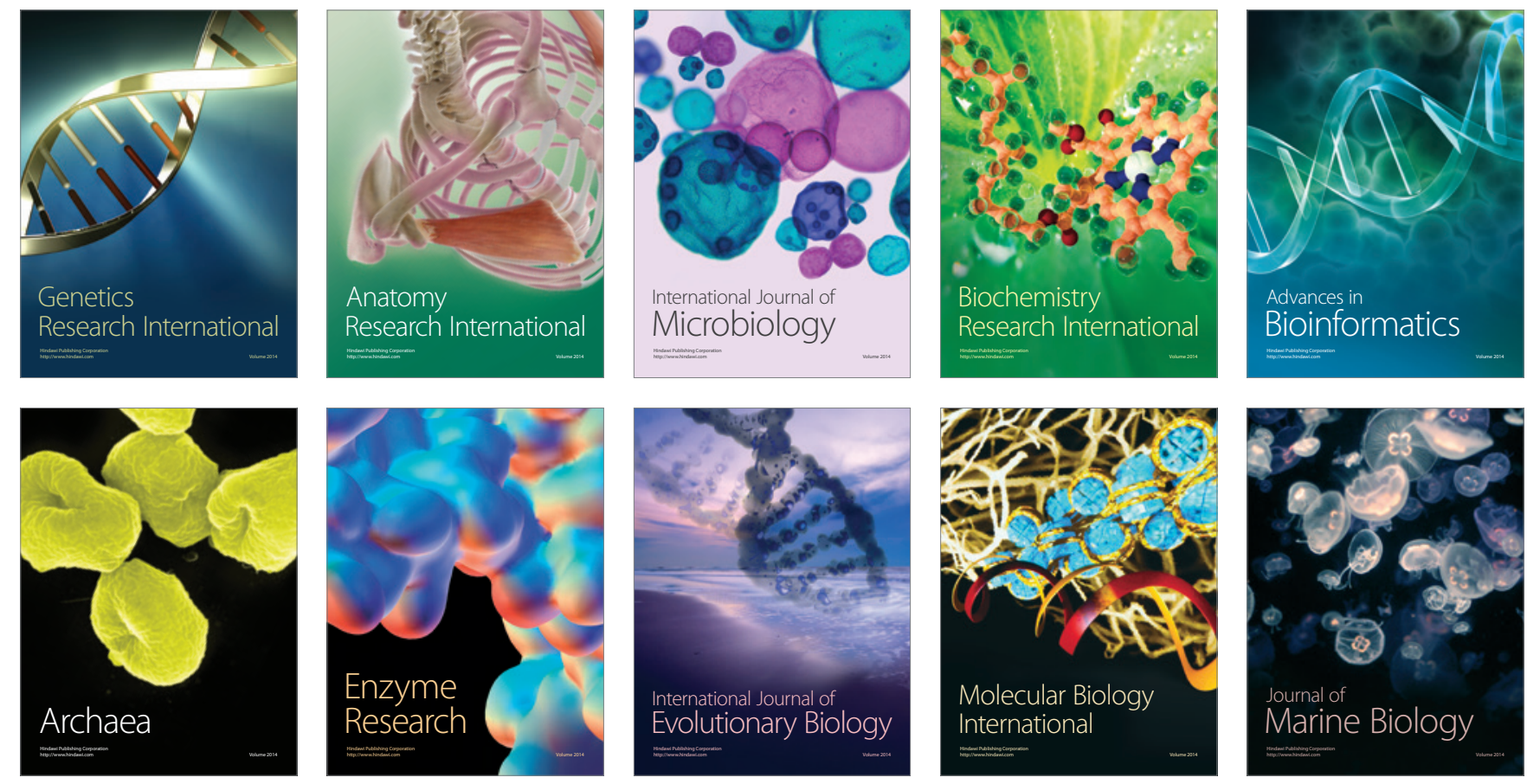